\title{
Economic Analysis of Guava (Psidium guajava L.) in Sonepat District of Haryana
}

\author{
Raj Kumar ${ }^{1 *}$, Nirmal Kumar ${ }^{1}$, Ashok Dhillon ${ }^{2}$, Dalip Kumar Bishnoi ${ }^{1}$, \\ Kavita $^{1}$ and Anil Kumar Malik ${ }^{3}$
}

${ }^{1}$ Department of Agricultural Economics, CCSHAU, Hisar, Haryana, India

${ }^{2}$ District Extension Specialist, Krishi Vigyan Kendra, Mahendragarh, Haryana, India

${ }^{3}$ Directorate of Extension Education, CCSHAU, Hisar, Haryana, India

*Corresponding author: rajkumarkashyap301@gmail.com (ORCID ID: 0000-0003-3089-6234)

Received: $18-06-2019$

Revised: $22-10-2019$

Accepted: 21-11-2019

\begin{abstract}
The present study has been designed to investigate cost of cultivation and returns per hectare of guava fruit. A sample of thirty guava farmers was taken purposively from various villages in Rai block of Sonepat district of Haryana. On the basis of the nature of data, various statistical and economic tools were used for estimation of cost and returns of guava production. The average first year establishment costs per hectare for guava has been worked out to be ₹ 77527. The per hectare per year returns from guava orchards have been worked out to be ₹ 223308. The economic viability of the guava, mainly net present value, internal rate of return, benefit-cost ratio and payback period have been computed as ₹ 599313.66, 26.11 per cent, 1:3.09 and 7 years, respectively. The findings of study shows that guava growing is a step towards the diversification and commercialization of agriculture in the state and it also helps in doubling the farmers' income. Keeping in view all the facts, there is need to develop early fruit bearing varieties of guava, timely supply of necessary inputs to make guava cultivation more profitable.

\section{Highlights}

(0 Guava growing is a step towards the diversification and commercialization of agriculture in the state and it also helps in doubling the farmers' income.
\end{abstract}

Keywords: Guava, returns, benefit-cost ratio, NPV, PBP and IRR

Guava (Psidium guajava L.), the "poor man's fruit" or "apple of the tropics" is a popular tree fruit of the tropical and subtropical climate and is native to the tropical America stretching from Mexico to Peru. It has been adopted in India having a production of 2.27 million metric tonnes with an area coverage of 0.20 million hectares (Kumar et al. 2017). Whereas among different states, Haryana is most important guava producing state comprising of 12089 hectare area under the crop and production 137022 MT during 2017-18 (Horticultural department government of Haryana). Now-a-day's guava is considered as one of the exquisite, nutritionally valuable and remunerative crop, which is used for both, fresh consumption and processing. In addition to this, it also gives good economic returns involving very little input, which has prompted several farmers to take up guava cultivation on a commercial scale. Whereas, marketing of guava crop is one of the major problem faced by the growers, which have a direct impact on their prosperity (Nandal and Punia, 2003). Therefore, an attempt has been made to assess the economic analysis of guava in Sonepat district of Haryana during the agricultural year 2017-18.

How to cite this article: Kumar, R., Kumar, N., Dhillon, A., Bishnoi, DK., Kavita and Malik, A.K. (2019). Economic analysis of guava (Psidium guajava L.) in sonepat district of Haryana. Economic Affairs, 64(4): 747-752. 


\section{MATERIALS AND METHODS}

Multistage stratified sampling technique was adopted to select the ultimate unit of sample. Out of twenty two districts of Haryana state Sonepat district was selected, on the basis of highest production which accounted about 14.96 per cent of total guava production in the state during 201718. A sample of thirty guava farmers was taken purposively from various villages in Rai block of Sonepat district of Haryana. Primary data pertaining to the year 2017-18 were collected from selected respondents by conducting personal interviews with help of specifically designed schedule.

\section{Amortization of fixed cost}

The annual amortization of cost was computed from the investment made on establishment of guava fruits, having 12 per cent rate of interest per annum as per bank guidelines and expected life of 25 years. Thus, annual amortization was worked out by using the compounding cost formula and by adding it to maintenance cost for estimating the annual cost of cultivation of guava fruits of respective farmers.

$$
I=B \frac{i}{1-(1+i)^{n}}
$$

Where,

$I=$ Annual cost (in ₹), $B=$ Present fixed cost (in ₹),$i$ $=$ Interest rate $(12 \%$ per annum $)$ and $n=$ Economic life of the guava orchard (in years).

\section{Economic viability}

To examine the economic feasibility of orchard while studying the economics of guava cultivation, four indicators were used viz., net present value (NPV), internal rate of return (IRR), cost benefit ratio and payback period. The detailed method used to find out these indicators are given below.

\section{Net present value}

Future net returns were discounted to their net present value by using the following formula:

$$
N . P . V .=\frac{R_{1}}{(1+r)^{1}}+\frac{R_{2}}{(1+r)^{2}}+\ldots+\frac{R_{n-1}}{(1+r)^{n-1}}+\frac{R_{n}}{(1+r)^{n}}
$$

Where, $R_{1}, R_{2} \ldots \ldots R_{n}$ are the net returns in the period $1,2, \ldots \ldots n$, respectively, ' $n$ ' is the life span in years of the investment in the guava orchard, ' $r$ ' is the discount rate (prevailing interest rate) and N.P.V. is net present value of returns $R_{1^{\prime}} R_{2^{\prime}} R_{3} \ldots \ldots \ldots R_{n}$.

\section{Internal rate of return}

In estimating the internal rate of return, the investment cost and incremental gross returns for each year in the life of guava orchard were calculated. The internal rate of return was calculated at the different rate of discount until it satisfies the relationship $B-C=0$ where ' $B$ ' is the sum of discounted stream of positive value (returns) and ' $C$ ' is taken as the sum of discounted stream of negative values (costs).

$\mathrm{IRR}=\left(\begin{array}{c}\text { Lower } \\ \text { discount } \\ \text { rate }\end{array}\right)+\left(\begin{array}{c}\text { Difference } \\ \text { between two } \\ \text { discount rates }\end{array}\right) \times \frac{\left(\begin{array}{c}\text { Present worth of the cash flow } \\ \text { at lower discount rate }\end{array}\right)}{\left(\begin{array}{c}\text { Absolute difference between } \\ \text { the present worth of the cash flow } \\ \text { at two discount rates }\end{array}\right)}$

\section{Benefit: Cost ratio}

The benefit cost ratio is the ratio between the sum of discounted net benefits of returns $(R)$ and the sum of discounted cost $(K)$, i.e. $B=R / K$. If this ratio is greater than 1.00 then the investment in guava orchard is considered to be economically viable.

\section{Payback period}

It is the period within which the cost of guava orchard is fully recovered from its own returns. For this condition, the following relationship must be used,

$$
P B P=\sum_{j=1}^{n^{*}} C j \leq \sum_{j=1}^{n^{*}} B j
$$

\section{RESULTS AND DISCUSSION}

\section{Establishment cost of guava orchard}

The results presented in Table 1, indicated that the average total establishment cost of guava orchard in Sonepat district was estimated ₹ 77527 per hectare. The highest cost item of expenditure was permanent fencing which was worked out to be ₹ 14085 per hectare, that constitute 18.17 per cent followed by digging and filling of pits ₹ 10663 per hectare, contributing 13.75 per cent, plant ₹ 8250, which constituted 10.64 per cent, manures and fertilizers which was found to be ₹ 7465 per hectare, 
constituting 9.63 per cent to total establishment cost and plantation ₹ 6875, contributing 8.87 per cent of total establishment cost, equipments ₹ 6695 contributing 8.64 per cent, preparation of land and layout ₹ 6688 contributing 8.63 per cent and transportation of plants ₹ 6408 contributing 8.27 per cent. In case of guava plantation ₹ 11502 per hectare subsidy was provided by government under National Horticulture Mission (NHM) scheme to increase the area under guava cultivation in the state.

Table 1: Establishment cost of guava orchard in Sonepat district of Haryana

\begin{tabular}{|c|c|c|c|}
\hline S1. No. & Particulars & $\begin{array}{l}\text { Value (₹/ } \\
\text { hectare) }\end{array}$ & Percent \\
\hline 1 & Preparation of land and layout & 6688 & 8.63 \\
\hline 2 & Digging and filling of pits & 10663 & 13.75 \\
\hline 3 & Cost of irrigation & 2808 & 3.62 \\
\hline 4 & Cost of plant & 8250 & 10.64 \\
\hline 5 & Cost of replacement plant & 1420 & 1.83 \\
\hline 6 & Manures and fertilizer & 7465 & 9.63 \\
\hline 7 & Transportation of plant & 6408 & 8.27 \\
\hline 8 & Plantation cost & 6875 & 8.87 \\
\hline 9 & Intercultural operation & 3085 & 3.98 \\
\hline 12 & Permanent fencing & 14085 & 18.17 \\
\hline 13 & Cost of equipments & 6695 & 8.64 \\
\hline 14 & Miscellaneous & 3085 & 3.98 \\
\hline $\begin{array}{l}\text { Total } \\
\text { cost }\end{array}$ & & 77527 & 100 \\
\hline
\end{tabular}

\section{Operational cost of guava orchard}

It is clear from the data in the Table 2 that the operating cost per hectare increased over years because of higher expenses incurred on various inputs and hike in picking cost. This increase may be attributed to the direct relationship between the physical input requirement and age of the plants. The annual operating cost ranges from ₹ 45223 in the first year to ₹ 88914 per hectare in the seventh year. The operational cost keeps on increasing up to seventh year of the establishment of an orchard and thereafter it becomes more or less stabilized. The operational cost per hectare per annum from first to seventh years were found to be ₹ 13547.71 on plant protection (20.34\%), ₹ 11776.57 on manure and fertilizers $(17.68 \%)$, ₹ 9131.29 on intercultural and hoeing $(13.71 \%)$, ₹ 9080.14 on irrigation $(13.63 \%)$, ₹ 8802.29 on picking $(13.22 \%)$, ₹ 7136.00 on watch and ward (10.72\%) followed by ₹ 3991.57 on pruning and cutting $(5.99 \%)$, were the major constituents of operational cost of a guava orchard per annum per hectare. Similar findings were also reported by Naphade and Tingre (2008) and Sharma et al. (2006).

\section{Cost and returns from guava orchard}

Data presented in Table 3 reveals the cost and returns per hectare of guava orchard at different ages i.e. from the year of establishment to seventhyear age of orchard. It was observed that there was no production of guava up to the age of three years since the bearing of fruits usually starts after attaining three years of age. The per hectare production of fruits starts increasing gradually from nearly 53 quintals in fourth year to about 270 quintals in seventh year orchard age. However, after attaining the age of seven year it remain almost static with advance in age of the plants. Hence, the gross returns per hectare from guava orchard increase up to seventh year age of the plants. The gross returns per hectare worked out to be ₹ 422280 in the seventh year that was full bearing stage. This rate of return was expected to be more or less same up to age of 25 years.

Taking into account the rental value of land, amortized fixed cost, operational cost, expected depreciation on fixed investment and interest on operational cost, the net returns per hectare have been worked out over time. The total cost varied from ₹ 127753 per hectare in the first year to ₹ 198972 per hectare in the seventh year. The net returns from inter cropping ranges from ₹ 39223 to ₹ 16335 per hectare during the first year to fifth year of the guava orchard. Even after taking the returns from intercropping in the orchard the orchardist has to bear a loss of ₹ 88530, ₹ 101549, ₹ 118758 and ₹ 65519 per hectare in first, second, third and fourth year, respectively. During the fifth year the net returns become positive and worked out to be ₹ 8551 per hectare. The net returns scale up to seventh year i.e. ₹ 223308 per hectare and after that it become more or less stable up to the age of 25 years. The net returns were negative in first four initial years and then were found to be positive from the fifth year to seventh year and onwards. In the seventh year the cost and returns were almost stable as the orchard was fully matured. Net returns from guava orchard up to seventh year are presented in 
Table 2: Operational cost of guava orchard in Sonepat district of Haryana (₹/hectare)

\begin{tabular}{|c|c|c|c|c|c|c|c|c|c|c|}
\hline \multirow[b]{2}{*}{ S1. No. } & \multirow[b]{2}{*}{ Particulars } & \multicolumn{9}{|c|}{ Years } \\
\hline & & 1 & 2 & 3 & 4 & 5 & 6 & 7 & Total cost & $\begin{array}{l}\text { Average } \\
\text { cost per annum }\end{array}$ \\
\hline 1 & Manure and fertilizer & 10657 & 11162 & 11404 & 11723 & 12243 & 12438 & 12809 & 82436 & $11776.57(17.68)$ \\
\hline 2 & Plant protection & 12468 & 13090 & 13420 & 13935 & 13740 & 13963 & 14218 & 94834 & $13547.71(20.34)$ \\
\hline 3 & Pruning and cutting & - & - & 4743 & 5078 & 5660 & 6025 & 6435 & 27941 & $3991.57(5.99)$ \\
\hline 4 & Intercultural and hoeing & 7655 & 8600 & 8655 & 9113 & 9743 & 9938 & 10215 & 63919 & $9131.29(13.71)$ \\
\hline 8 & Watch and ward & 6150 & 6595 & 6853 & 7362 & 7465 & 7563 & 7964 & 49952 & $7136.00(10.72)$ \\
\hline 9 & Picking cost & - & - & - & 6585 & 12855 & 19733 & 22443 & 61616 & $8802.29(13.22)$ \\
\hline 10 & Miscellaneous & 1140 & 1748 & 1880 & 1973 & 2428 & 2800 & 3090 & 15059 & $2151.29(3.23)$ \\
\hline \multicolumn{2}{|c|}{ Total operational cost } & 45223 & 50135 & 57027 & 66177 & 75124 & 83577 & 88914 & 466177 & 66596.71(100) \\
\hline
\end{tabular}

Figures in parentheses are the percentage to the average cost per annum

Table 3: Cost and return from guava orchard in Sonepat district of Haryana ( $₹ /$ hectare)

\begin{tabular}{|c|c|c|c|c|c|c|c|c|}
\hline \multirow{2}{*}{$\begin{array}{l}\text { Sl. } \\
\text { No. }\end{array}$} & \multirow[t]{2}{*}{ Particulars } & \multicolumn{7}{|c|}{ Years } \\
\hline & & 1 & 2 & 3 & 4 & 5 & 6 & 7 \\
\hline 1 & Rental value of land & 64118 & 69725 & 72808 & 75640 & 82469 & 83910 & 86407 \\
\hline 2 & Amortized fixed cost & 9885 & 9885 & 9885 & 9885 & 9885 & 9885 & 9885 \\
\hline 3 & Operational cost & 45223 & 50130 & 57030 & 66175 & 75123 & 83573 & 88910 \\
\hline 4 & Expected depreciation on fixed cost investment $@ 4 \%$ & 3101 & 3101 & 3101 & 3101 & 3101 & 3101 & 3101 \\
\hline 5 & Interest on operational cost @12\% PA & 5427 & 6016 & 6844 & 7941 & 9015 & 10029 & 10669 \\
\hline 6 & Total cost (1 to 5$)$ & 127753 & 138857 & 149668 & 162742 & 179592 & 190497 & 198972 \\
\hline 7 & Production (qtls) & - & - & - & 53 & 118 & 188 & 270 \\
\hline 8 & Price (₹/qtls) & - & - & - & 1345 & 1456 & 1510 & 1564 \\
\hline 9 & Gross returns\# & - & - & - & 71285 & 171808 & 283880 & 422280 \\
\hline 10 & Net returns & -127753 & -138857 & -149668 & -91457 & -7784 & 93383 & 89323 \\
\hline 11 & Return from inter cropping & 39223 & 37308 & 30910 & 25938 & 16335 & - & - \\
\hline Tota & et returns & -88530 & -101549 & -118758 & -65519 & 8551 & 93383 & 223308 \\
\hline
\end{tabular}

\# Gross return has been worked out by taking average price ('1564 per quintal) received by farmers during peak marketing season of the current period in Sonepat market.

Fig. 1. Nandal and Punia (2003) also revealed that net return per acre from guava orchard was ₹ 45248 . On an average the cost of production per quintal was found to be ₹ 136.77 for guava cultivation. Economics of guava crop cultivation shows that grower had to face losses during the first three years of cultivation. The net present value for one hectare guava orchard was ₹ 599313.66. A very high internal rate of return of 26.11 per cent per annum pointed that investment on guava orchards is highly profitable and internal rate of return exceed than present market interest rate. At discount rate of 12 per cent, on an average the benefit cost ratio was found 1:3.09. The payback period of investment of guava orchard was found to be seven years. Similar findings were also reported by Kumbhar et al. (2014) and Kumar et al. (2019).

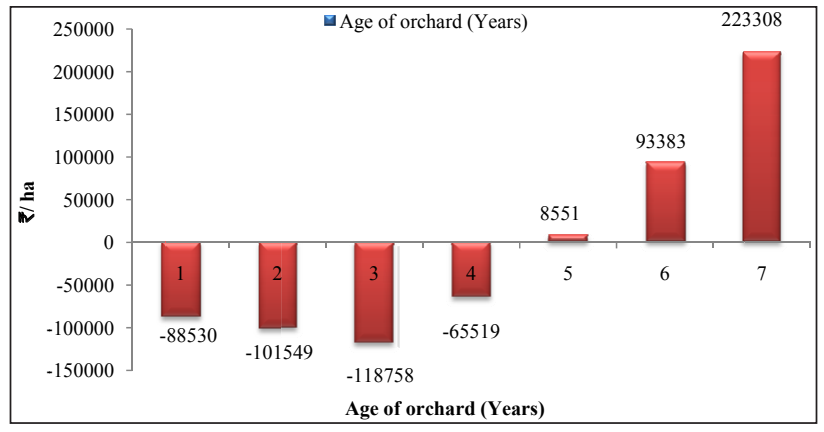

Fig. 1: Net returns from guava orchard

\section{Economic viability of guava orchard}

To examine the economic feasibility of guava orchard, four indicators were used viz., net present value (NPV), and internal rate of returns (IRR), benefit-cost ratio and payback period which are discussed as below: 


\section{Net present value (NPV) of guava orchard}

Costs and returns data presented in Tables 3 do not serve as true guide for making choice to go for guava orchard vis-à-vis other annual crops. This was due to the fact that cost incurred and returns gained from guava orchard over time are not comparable with annual crops grown in the area. Returns from investment in annual crops can be obtained within a year, while minimum three to four years period must be lapsed after planting before any returns are obtained over operational costs from guava orchards. Hence, it is necessary to estimate the net present value of future returns which can be determined by discounting both the costs as well as returns at the prevailing rate of interest. In the present study the prevailing interest rate of 12 per cent per annum was taken as discount rate of the costs and returns to determine NPV of the guava orchard.

Table 4: Per hectare net present value of guava orchard in Sonepat district of Haryana $(r=12 \%)$

\begin{tabular}{|c|c|c|c|c|c|}
\hline \multirow[b]{2}{*}{ ‡ } & \multirow[b]{2}{*}{ 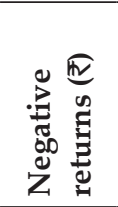 } & \multirow[b]{2}{*}{ 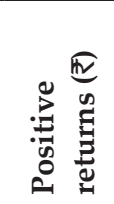 } & \multirow[b]{2}{*}{ 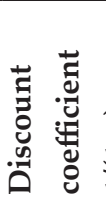 } & \multicolumn{2}{|c|}{ Present value } \\
\hline & & & & 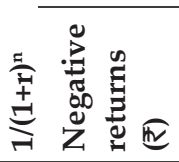 & 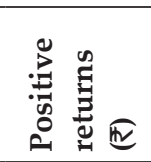 \\
\hline 1 & -88530 & - & 0.8929 & -79044.89 & - \\
\hline 2 & -101549 & - & 0.7972 & -80953.92 & - \\
\hline 3 & -118758 & - & 0.7118 & -84529.31 & - \\
\hline 4 & -65519 & - & 0.6355 & -41638.51 & - \\
\hline 5 & - & 8551 & 0.5674 & - & 4851.95 \\
\hline 6 & - & 93383 & 0.5066 & - & 47310.63 \\
\hline $\begin{array}{l}7 \text { (and } \\
\text { onward } \\
\text { up to } 25 \\
\text { years) }\end{array}$ & - & 223308 & 3.7317 & - & 833317.72 \\
\hline Total & -374355 & 325242 & - & -286166.64 & 885480.30 \\
\hline
\end{tabular}

Net present value $(\mathrm{NPV})=885480.30-286166.64$ $=599313.66$

The net present value thus computed is showed in Table 4. The figure given in this table showed that net present values (NPVs) for one hectare guava orchard was ₹ 599313.66 for the entire life (25 years) of the guava orchard. The positive NPV of guava cultivation is a profitable crop enterprise in the Sonepat district of the state.

\section{Internal rate of return (IRR) of guava orchard}

In estimating the internal rate of return, the investment cost, gross returns from first to seventh year and the life of guava orchard have been depicted in Tables 5 . The net cash flow was obtained by using these single values which may have negative and positive signs according to quantum of costs and benefits or returns in every year.

Table 5: Internal rate of return from one hectare of guava orchard in Sonepat district of Haryana (₹/ hectare)

\begin{tabular}{|c|c|c|c|c|c|}
\hline ప્ర & 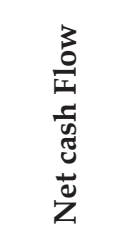 & 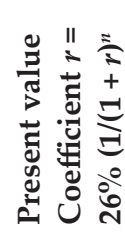 & 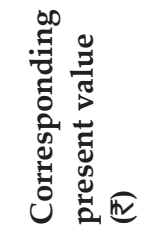 & 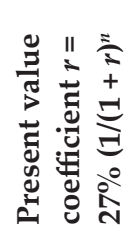 & 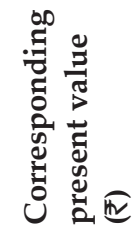 \\
\hline 1 & -88530 & 0.7937 & -70262.13 & 0.8333 & -73775.23 \\
\hline 2 & -101549 & 0.6299 & -63963.59 & 0.6944 & -70519.86 \\
\hline 3 & -118758 & 0.4999 & -59367.64 & 0.5787 & -68725.46 \\
\hline 4 & -65519 & 0.3968 & -25994.72 & 0.4823 & -31596.74 \\
\hline 5 & 8551 & 0.3149 & 2692.49 & 0.4019 & 3436.37 \\
\hline 6 & 93383 & 0.2499 & 23336.92 & 0.3349 & 31273.71 \\
\hline $\begin{array}{l}\text { 7.(and } \\
\text { onward up } \\
\text { to } 25 \text { years) }\end{array}$ & 223308 & 0.9493 & 211986.09 & 1.6221 & 362227.58 \\
\hline Total & - & - & 18427.43 & - & 152320.37 \\
\hline
\end{tabular}

To find out the present value, the discounted rate was estimated by different discount rate at random until the difference between the sum of discounted streams of positive and negative values is reduced either to zero or to a lowest minimum value. Thus, computed values of internal rate of returns are shown in Tables 5. The data presented in this Table indicates a very high internal rate of return of 26.11 per cent per annum indicating that investment on guava orchards is highly profitable and internal rate of return is comparatively more than the present market interest rate i.e. 12 per cent per annum.

\section{Benefit-Cost ratio of guava orchard}

At discount rate of 12 per cent, on an average the benefit cost ratio obtained was equal to 1:3.09. It indicates that at the prevailing rate of interest at 12 per cent per annum on investment of ₹ 1.00 would fetch a return of ₹ 3.09. Since this ratio was greater than unity, it shows that the investment in guava orchard is considered to be economically viable. Nandal and 
Punia (2003) reported similar observation that the IRR, net present value, benefit-cost ratio and payback period of guava have been observed 17.25 per cent, ₹ 200099.75 per acre, 1:4.02 and 8 years, respectively.

\section{Payback period of guava orchard}

As depicted in Table 3, the net cost incurred during the first five years of the guava plantation was ₹ 374355 per hectare. These costs are more than the return of ₹ 325242 per hectare. These costs are fully recovered in seventh year of establishment of guava plantation. Thus, the payback period of investment of guava orchard is seven year. Bhat et al. (2011) reported similar observation that the IRR, net present value, benefit-cost ratio and payback period of kinnow have been observed to vary from 14.75 per cent to 16.00 per cent, ₹ 7468 to ₹ 11649 per acre, 1:1.07 to $1: 1.65$ and 7.2 to 7.8 years, respectively, depending on the size of the orchards.

\section{CONCLUSION}

In the light of above discussion, it may be said that although the initial investment in guava orchard establishment is very high yet it is an economically viable enterprise. Per hectare establishment cost of guava orchard was estimated ₹ 77527. The total cost varied from $₹ 127753$ per hectare in the first year to ₹ 198972 per hectare in seventh year. Average per year net return for the sample as a whole was ₹ 223308 among the different age groups of guava orchard. The economic viability of the guava, mainly net present value, internal rate of return, benefit-cost ratio and payback period have been computed as ₹ 599313.66, 26.11 per cent, 1:3.09 and 7 years, respectively. The orchards indicating that guava cultivation was a profitable enterprise. It has a vital potential in increasing the income and gainful employment of family community. Guava growing is a step towards the diversification and commercialization of agriculture in the Haryana state.

\section{SUGGESTIONS AND POLICY IMPLICATIONS}

Keeping in view the findings of the present study it is suggested that the guava fruit growers, policy makers and researchers to make profitable enterprises by taking these steps.
- The early fruit bearing varieties should be developed to make guava fruit profitable.

- Quality planting material suited to the area should be provided to the farmers.

- Insurance of guava orchard should be encouraged at lower insurance premium to minimize the risk due to natural hazards.

- The government should make adequate arrangement for timely supply of necessary inputs at reasonable prices to the growers so as to increase per hectare productivity as well as net returns.

\section{ACKNOWLEDGEMENTS}

Authors wish to acknowledge Chaudhary Charan Singh Haryana Agricultural University and all the farmers who participated in the study and made the study successful.

\section{REFERENCES}

Anonymous. 2017. Indian horticulture database. National horticulture board, Ministry of agriculture and farmer's welfare Government of India, Gurugram. http://www.nhb. gov.in Accessed on 29 June 2019.

Bhat, A., Kachroo, J. and Kachroo, D. 2011. Economic appraisal of kinnow production and its marketing under north -western himalayan region of Jammu. Agril. Eco. Res. Rev., 24: 283-290.

Kumar, N., Duhan, A., Bhatia, J. and Malik, V. 2017. Economic appraisal of kinnow production and its marketing in Sirsa district of Haryana, India. Int. J. Cur. Microb. Appl. Sci., 6(11): 4045-4053.

Kumar, N., Malik, D.P., Kumar, R. and Sumit 2019. An economic analysis of mango (Mangifera indica L.) cultivation in Haryana. Indian J. Eco. Dev., 15(2): 282-288.

Kumbhar, J.S., Pawar, P.P., Patole, S.D. and Gavali, A.S. 2014. Economics of production and marketing of guava in Maharashtra. Int. J. Agril. Sci., 10(2): 592-599.

Nandal, R.S. and Punia, Deep 2003. A study on economics of major vegetable and fruit crop in Haryana state. research bulletin, Department of agricultural economics CCS HAU, Hisar. Res. Bulletin. no.: 50.

Naphade S.A. and Tingre, A.S. 2008. Economics of production and marketing of guava in Buldhana district of Maharashtra. Ind. J. Agril. Mark., 22(2): 32-41.

Sharma, D.K., Singh, V.K., Khatkar, R.K. and Sharma, S. 2006. An economic analysis of mango cultivation in Yamunanagar district of Haryana. Haryana Agric. Univ. J. Res., 36: 105-111. 